\title{
Efektivitas Macromedia Flash Dan Youtube Dalam Pembelajaran Pendidikan Jasmani Pada Masa Covid-19 Di Kota Palangkaraya
}

\author{
${ }^{1}$ Yudo Harvianto, ${ }^{2}$ Garry William Dony, ${ }^{3}$ Bernisa \\ Pendidikan Jasmani, Kesehatan dan Rekreasi, FKIP Universitas Palangka Raya \\ e-mail : yudo@fkip.upr.ac.id
}

\begin{abstract}
The Coronavirus - 19 (Covid-19) pandemic has made all school programs from the curriculum section experience changes in learning. These changes lead to an online learning system (in a network) in the form of maximum use of technology. The pandemic requires all educators and students to enter the world of technology. One way to increase effectiveness is by utilizing information and communication technology (ICT) such as macromedia flash and youtube applications. Especially with the increasing advancement of technology globally today and the covid-19 pandemic, it is very important for a physical education educator to have good skills about information technology, so that it can be used as a learning medium. The main objective of this research is to know the effectiveness of macromedia flash and youtube in learning physical education during Covid-19 in the city of Palangka Raya. The research method used by researchers is experimental with pre-experimental design. Researchers used a quantitative approach in the implementation of this research. The experimental method in this research is used to measure the changes that occur after treatment. $T$ test in this research using the Minitab application. The results of this research based on the T test for two paired samples showed P-Value $<\alpha(0.000<0.05)$ so that Ho was rejected. Based on these results, it shows that the use of macromedia flash and youtube applications has a positive impact and is proven to be effective in improving student learning outcomes in physical education learning.
\end{abstract}

Keywords : Effectiveness, Physical Education, Macromedia-Flash, Youtube, Covid - 19

Abstrak . Dengan adanya pandemi Coronavirus - 19 (COVID 19), seluruh program sekolah dari bidang kurikulum mengalami perubahan pembelajaran. Perubahan tersebut menuju ke sistem pembelajaran daring (dalam jaringan) berupa pemanfaatan teknologi secara maksimal. Dari adanya pandemi ini, maka seluruh tenaga pendidik dan peserta didik akan dituntut untuk terjun ke dunia teknologi. Salah satu cara untuk meningkatkan efektivitas yaitu dengan memanfaatkan information and communication technology (ICT) berupa aplikasi macromedia flash dan youtube. Terlebih dengan bertambah majunya teknologi secara global saat ini serta adanya pandemi covid-19, maka menjadi sangat penting bagi seorang tenaga pendidik pendidikan jasmani memiliki keterampilan yang baik tentang teknologi informasi, sehingga dapat dijadikan sebagai media pembelajaran. Adapun yang menjadi tujuan utama dalam penelitian ini yaitu untuk mengetahui efektivitas macromedia flash dan youtube dalam pembelajaran pendidikan jasmani pada masa Covid-19 di kota Palangka Raya. Metode penelitian yang digunakan peneliti adalah eksperimen dengan desain pre-eksperimental. Peneliti menggunakan pendekatan kuantitatif dalam pelaksanaan penelitian ini. Metode eksperimen dalam penelitian ini digunakan untuk mengukur perubahan yang terjadi setelah dilakukannya perlakuan. uji $\mathrm{T}$ dalam penelitian ini menggunakan aplikasi Minitab. Hasil dari penelitian ini berdasarkan uji T untuk dua sampel berpasangan menunjukkan P-Value $<\alpha(0,000<$ 0,05) sehingga Ho ditolak. Berdasarkan hasil ini menunjukkan bahwa penggunaan aplikasi macromedia flash dan youtube memberikan dampak positif dan terbukti efektif terhadap peningkatan hasil belajar peserta didik dalam pembelajaran pendidikan jasmani.

Kata Kunci : Efektivitas, Pendidikan Jasmani, Macromedia-Flash, Youtube, Covid - 19 


\section{PENDAHULUAN}

Tidak bisa dipungkiri lagi bahwa pendidikan sangat penting bagi kehidupan, sebab pendidikan dapat mempengaruhi kualitas hidup dan merubah keadaan sosial manusia. Terlebih, tolak ukur kemajuan dan perkembangan pendidikan menjadi faktor utama keberhasilan suatu bangsa. Pendidikan jasmani merupakan suatu proses pembelajaran yang dilakukan secara sistematis melalui dan didominasi oleh aktivitas fisik dengan tujuan untuk mendapatkan kebugaran jasmani. Menurut Harvianto (2020:1) bahwa Salah satu aktivitas yang dibutuhkan dalam kehidupan sehari-hari manusia yaitu aktivitas fisik atau olahraga.

Melalui pendidikan jasmani juga dapat membantu peserta didik dalam pertumbuhan fisik, perkembangan kognitif, keterampilan motorik, serta kematangan afektif. Sehingga pembelajaran pendidikan jasmani disekolah sangat diperlukan oleh peserta didik.

Oleh karena itu untuk tercapainya tujuan dari pembelajaran pendidikan jasmani, hendaknya guru melaksanakan proses pembelajaran secara efektif. Salah satu cara untuk meningkatkan efektivitas yaitu dengan memanfaatkan Information and Communication Technology (ICT) berupa aplikasi macromedia flash dan youtube. Terlebih dengan bertambah majunya teknologi secara global saat ini, maka menjadi sangat penting bagi seorang tenaga pendidik pendidikan jasmani memiliki keterampilan yang baik tentang teknologi informasi, sehingga dapat dijadikan sebagai media pembelajaran.

Kemudian ditambah lagi dengan adanya pandemi Coronavirus - 19 (COVID 19), seluruh program sekolah dari bidang kurikulum akan mengalami perubahan pembelajaran. Perubahan tersebut pastinya menuju ke Sistem Pembelajaran Daring (Dalam Jaringan) berupa pemanfaatan ICT secara maksimal. Dari adanya pandemi ini, maka seluruh tenaga pendidik dan peserta didik akan dituntut untuk terjun ke dunia teknologi.

Berdasarkan latar belakang itulah, peneliti melakukan penelitian tentang efektivitas macromedia flash dan youtube dalam pembelajaran Pendidikan Jasmani pada masa Covid-19 di Kota Palangka Raya”.
Adapun yang menjadi tujuan utama dalam penelitian ini yaitu untuk mengetahui efektivitas macromedia flash dan youtube dalam pembelajaran Pendidikan Jasmani pada masa Covid-19 di Kota Palangka Raya.

\section{METODE}

Metode penelitian yang digunakan peneliti adalah metode eksperimen dengan desain preeksperimental. Peneliti menggunakan pendekatan kuantitatif dalam pelaksanaan penelitian ini. Metode eksperimen dalam penelitian ini digunakan untuk mengukur perubahan yang terjadi setelah dilakukannya perlakuan.

Dalam penelitian ini, peneliti memberikan tes awal (pretest) pada peserta didik guna mengetahui sejauh mana pengetahuan yang dimiliki peserta didik mengenai pembelajaran pendidikan jasmani. Setelah diberikan tes awal, peneliti melakukan eksperimen dengan memberikan perlakuan berupa pembelajaran jarak jauh. Pembelajaran jarak jauh atau online dengan media ICT berbentuk video pembelajaran interaktif di youtube dan aplikasi macromedia flash.

Kegiatan akhir yang peneliti lakukan yaitu dengan memberikan tes akhir (posttest), dengan tujuan untuk mendapatkan perbandingan data dari tes awal (pretest) ke tes akhir (posttest).

\section{HASIL DAN PEMBAHASAN \\ Hasil}

\section{Deskripsi Data Hasil Tes}

Hasil perhitungan data pretes dan postes pada SMKN 3 Palangka Raya, MA Miftahul Jannah, dan Mahasiswa PJKR FKIP UPR dapat dilihat pada Tabel 4.1.

\section{Tabel 4.1 Data Nilai Pretes dan Postes}

\begin{tabular}{|c|c|c|c|c|c|c|}
\hline \multirow{2}{*}{ Statistika } & \multicolumn{2}{|c|}{$\begin{array}{c}\text { SMKN 3 } \\
\text { P.Raya }\end{array}$} & \multicolumn{2}{c|}{$\begin{array}{c}\text { MA Miftahul } \\
\text { Jannah }\end{array}$} & \multicolumn{2}{|c|}{ Mahasiswa } \\
\cline { 2 - 7 } & $\mathbf{1}$ & $\mathbf{2}$ & $\mathbf{1}$ & $\mathbf{1}$ & $\mathbf{1}$ & $\mathbf{2}$ \\
\hline Jumlah Siswa & 29 & 29 & 25 & 25 & 38 & 38 \\
\hline Nilai tertinggi & 48 & 80 & 80 & 88 & 88 & 96 \\
\hline Nilai terendah & 12 & 60 & 60 & 76 & 48 & 76 \\
\hline Rata-rata & 30 & 68 & 70 & 81 & 71 & 87 \\
\hline
\end{tabular}

Ket : 1 (Pretes), 2 (postes)

Data hasil pretes menunjukkan bahwa hasil belajar peserta didik cenderung rendah. Sedangkan setelah penggunaan aplikasi Macromedia Flash dan Youtube dalam Pembelajaran Penjas dapat dilihat dari data hasil 
postes yang menunjukkan bahwa terjadi peningkatan hasil belajar.

Adapun perbandingan nilai rata-rata hasil pretes dan postes dapat dilihat pada Gambar 4.1.

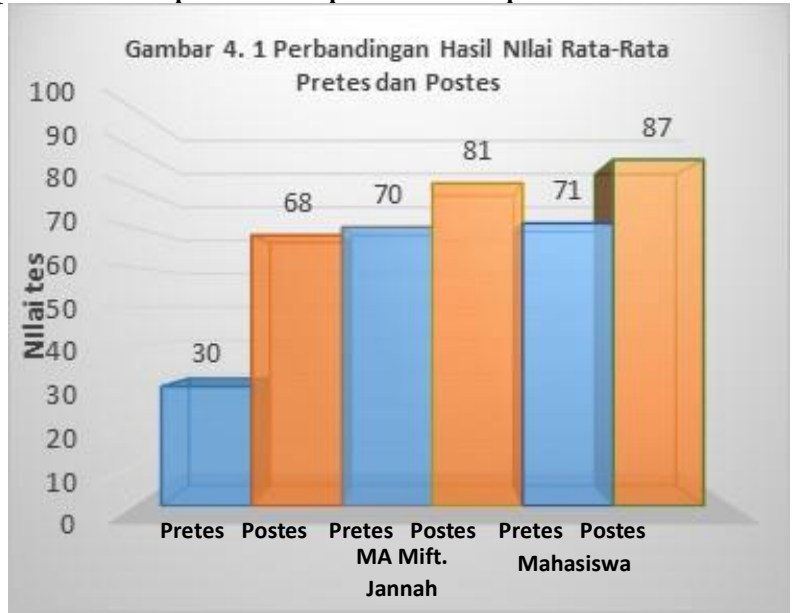

2. Uji Prasyarat Analisis Data

a. Uji Normalitas Data Pretes-Postes Siswa SMKN 3 Palangka Raya

Uji normalitas dalam penelitian ini menggunakan uji kolmogorov-Smirnov melalui aplikasi Minitab. Hasil uji normalitas data pretes dan postes siswa SMKN 3 Palangkaraya dapat dilihat pada gambar 4.2.

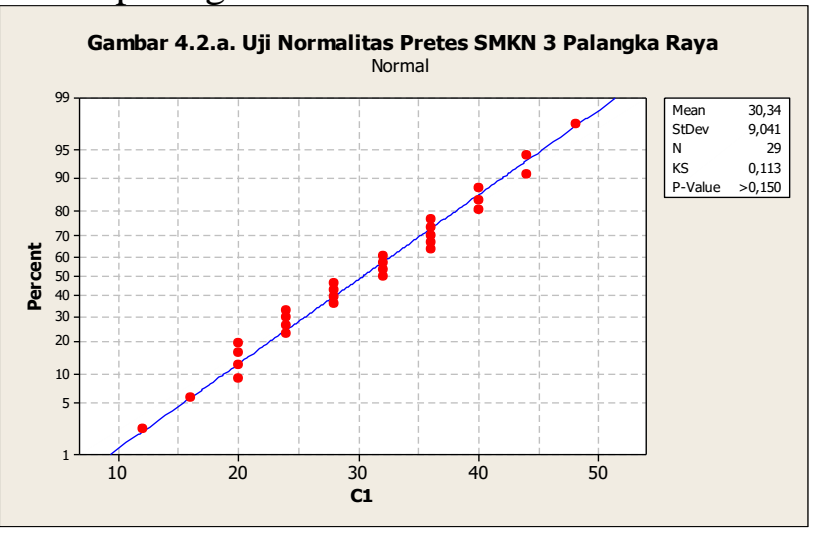

Hasil P-Value nilai pretes menunjukan bahwa data beristribusi normal karena telah memenuhi kriteria $\mathrm{P}-$ Value $>\alpha$ yaitu $(>0,150>$ $0,05)$.

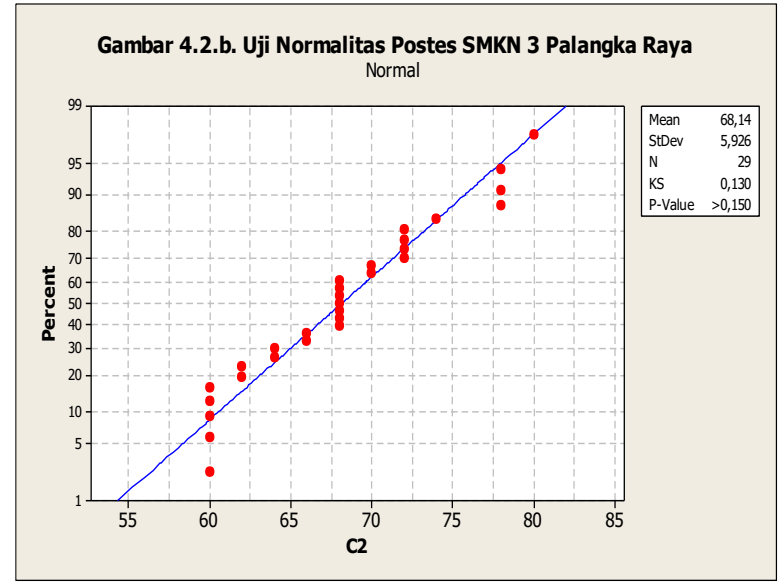

Hasil P-Value nilai postes menunjukan bahwa data beristribusi normal karena telah memenuhi kriteria P-Value $>\alpha$ yaitu $(>0,150>$ $0,05)$.

b. Uji Normalitas Data Pretes dan Postes Siswa MA Miftahul Jannah

Hasil uji normalitas data pretes dan postes siswa MA Miftahul Jannah Palangka Raya dapat dilihat pada gambar 4.3.

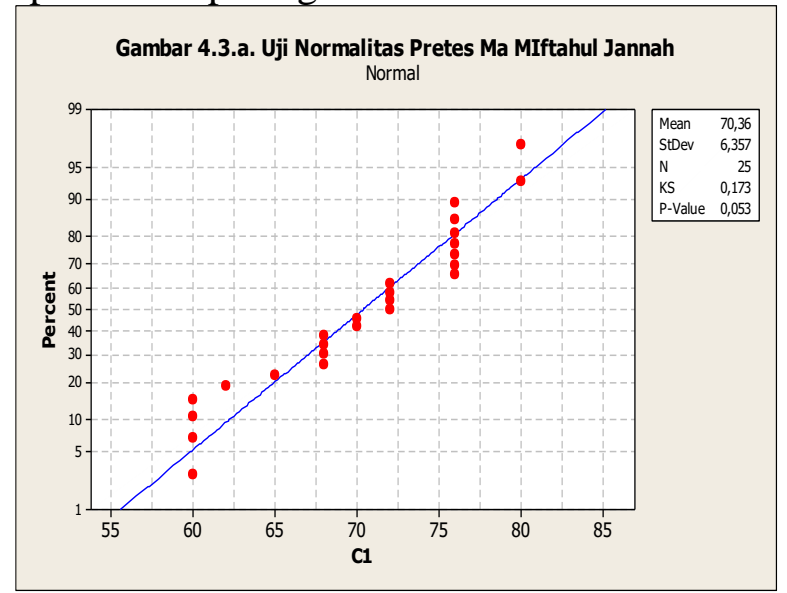

Hasil P-Value nilai pretes menunjukan bahwa data beristribusi normal karena telah memenuhi kriteria P-Value $>\alpha$ yaitu $(0,053>$ $0,05)$.

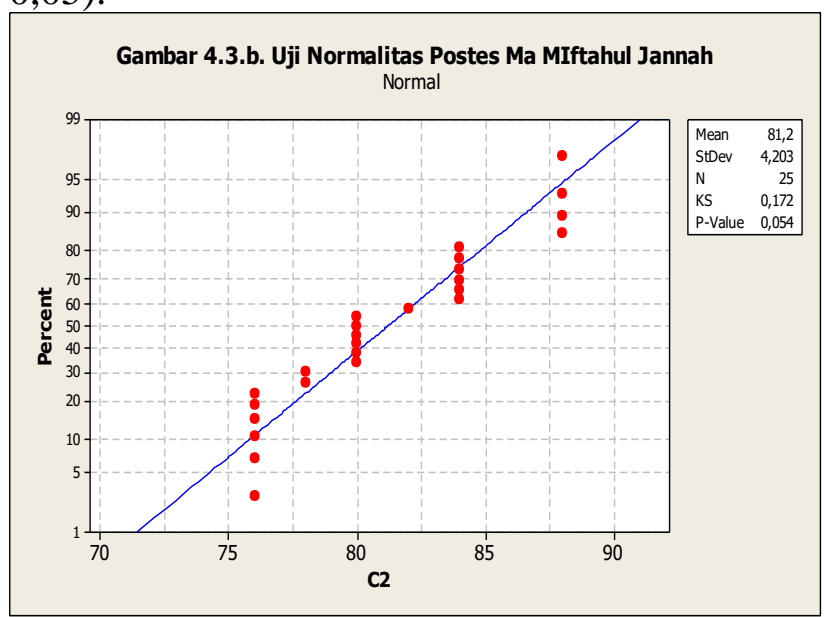


Hasil P-Value nilai postes menunjukan bahwa data beristribusi normal karena telah memenuhi kriteria $\mathrm{P}-$ Value $>\alpha$ yaitu $(0,054>$ $0,05)$.

\section{c. Uji Normalitas Data Pretes dan Postes Mahasiswa PJKR FKIP UPR}

Hasil uji normalitas data pretes dan postes mahasiswa PJKR FKIP UPR dapat dilihat pada gambar 4.4.

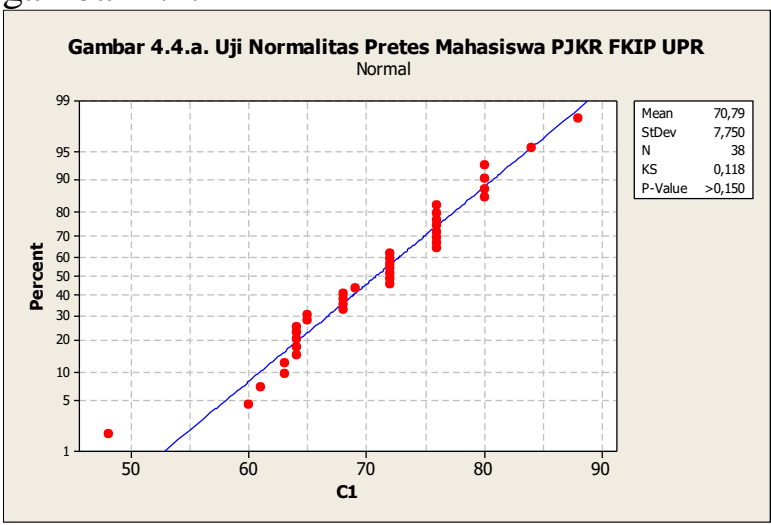

Hasil P-Value nilai pretes menunjukan bahwa data beristribusi normal karena telah memenuhi kriteria P-Value $>\alpha$ yaitu $(>0,150>$ $0,05)$.

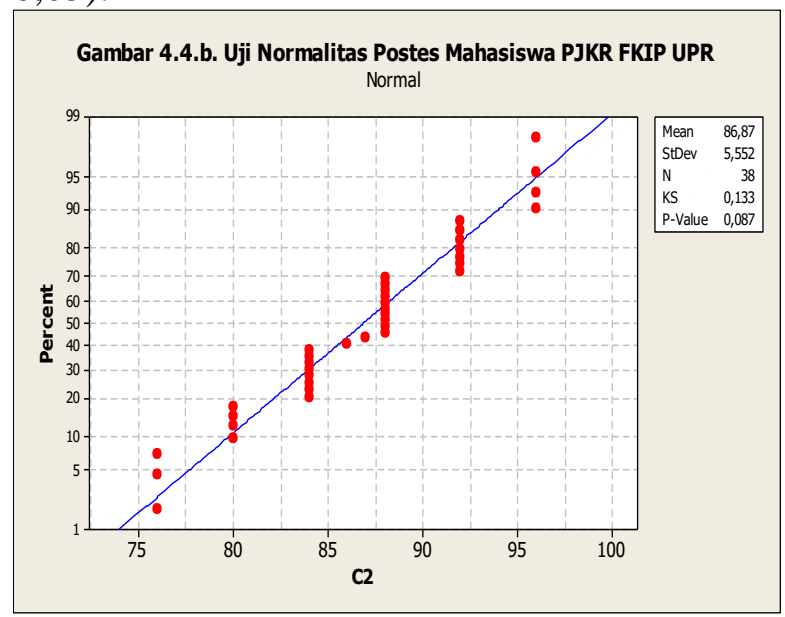

Hasil P-Value nilai postes menunjukan bahwa data beristribusi normal karena telah memenuhi kriteria P-Value $>\alpha$ yaitu $(0,087>$ $0,05)$.

\section{Pengujian Hipotesis}

Setelah dilakukan uji prasyarat analisis data, diketahui bahwa data hasil pretes dan postes pada penelitian ini berdistribusi normal, sehingga penggujian data selanjutnya menggunakan uji statistik parametrik yaitu Uji $\mathrm{T}$ untuk dua sampel berpasangan. Uji $\mathrm{T}$ dalam penelitian ini menggunakan aplikasi Minitab. Pengujian hipotesis ini dilakukan untuk mengetahui apakah terdapat perbedaan hasil belajar peserta didik dengan penggunaan aplikasi Macromedia Flash dan Youtube terhadap Pembelajaran Penjas.

Adapun kriteria hasil Uji T untuk dua sampel berpasangan yaitu jika nilai $\mathrm{P}-$ Value $\leq \alpha$ maka Ho ditolak yang artinya terdapat perbedaan hasil belajar peserta didik dengan Penggunaan aplikasi Macromedia Flash dan Youtube terhadap Pembelajaran Penjas. Sedangkan jika $\mathrm{P}$-Value $>\alpha$ maka Ho diterima yang artinya tidak terdapat perbedaan hasil belajar peserta didik dengan Penggunaan aplikasi Macromedia Flash dan Youtube terhadap Pembelajaran Penjas. Hasil Uji $T$ untuk dua sampel berpasangan dapat dilihat pada tabel 4.2.

Tabel 4.2 Uji T untuk Dua Sampel Berpasangan

\begin{tabular}{|c|c|c|}
\hline \multicolumn{3}{|c|}{ Hasil } \\
\hline P-Value & $\alpha$ & Ket. \\
\hline $0,000<$ & 0,05 & $\begin{array}{c}\text { Ho } \\
\text { ditolak }\end{array}$ \\
\hline
\end{tabular}

Berdasarkan tabel diatas dapat disimpulkan bahwa terdapat perbedaan hasil belajar peserta didik dengan Penggunaan aplikasi Macromedia Flash dan Youtube terhadap Pembelajaran Penjas.

\section{Pembahasan}

Data hasil pretes menunjukkan bahwa hasil belajar peserta didik cenderung rendah. Kemudian setelah dilakukan perlakuan dengan penggunaan aplikasi Macromedia Flash dan Youtube kepada peserta didik dalam Pembelajaran Penjas menunjukkan bahwa terjadi peningkatan hasil belajar. Ini membuktikan bahwa perlakuan yang digunakan dengan menggunakan ICT guna peningkatan hasil belajar terbilang berhasil. Hal ini sejalan dengan apa yang dikatakan oleh Stanescu, dkk (2011) bahwa penggunaan ICT akan membuat proses pembelajaran menjadi efektif. Sebab dengan terjadinya pembelajaran yang efektif maka akan meningkatkan terhadap informasi yang diberikan melalui metode pembelajaran visual, audio dan kinestetik dalam pembelajaran. 
Dalam artian bahwa aplikasi Macromedia Flash dan Youtube bisa dijadikan sebagai media pembelajaran yang dapat dimanfaatkan oleh tenaga pendidik baik dosen maupun guru, dalam bentuk terpisah maupun gabungan antara aplikasi satu dengan yang lainnya guna kepentingan belajar mengajar, dengan tujuan utama yaitu meningkatkan efektivitas pembelajaran guna tercapainya tujuan pembelajaran. Sebab tujuan pembelajaran sangat dipengaruhi oleh media yang digunakan tenaga pendidik dalam proses belajar mengajar.

Pernyataan diatas senada dengan apa yang dikatakan oleh Collins (2011: 29), menurutnya dengan semakin majunya teknologi informasi secara global saat ini, maka menjadi penting bagi seorang guru pendidikan jasmani memiliki pengetahuan yang mendalam tentang teknologi informasi, sehingga dapat dijadikan sebagai media pembelajaran.

\section{KESIMPULAN}

Kesimpulan dari penelitian ini menunjukkan bahwa penggunaan aplikasi Macromedia Flash dan Youtube memberikan dampak positif dan terbukti efektif terhadap peningkatan hasil belajar peserta didik dalam Pembelajaran Penjas. Pemanfaatan ICT berupa aplikasi dan media pembelajaran sangat tepat digunakan untuk membantu tenaga pendidik yaitu dosen dan guru dalam memahamkan materi pembelajaran kepada peserta didik di masa COVID-19, yang tidak memungkinkan adanya pembelajaran secara tatap muka. Selain itu, juga menjadi sebuah tuntutan teknologi dalam dunia pendidikan karena dunia telah memasuki era industri 4.0. Sehingga relevan jika dunia pendidikan lebih membiasakan pembelajaran menggunakan aplikasi dan media pembelajaran berbasis ICT.

\section{SARAN}

Semakin majunya teknologi informasi secara global saat ini, maka menjadi penting bagi tenaga pendidik pendidikan jasmani memiliki pengetahuan yang mendalam tentang teknologi informasi, sehingga dapat dijadikan sebagai media pembelajaran. Oleh karenanya diharapkan kedepan adanya pelatihan-pelatihan untuk tenaga pendidik tentang media pembelajaran berbasis ICT.

\section{DAFTAR PUSTAKA}

A.M Bandi Utama. (2011). Pembentukan Karakter Bermain Anak Melalui Aktivitas Bermaian Dalam Pendidikan Jasmani. Yogyakarta : Jurusan Pendidikan Olahraga. FIK. UNY.

Aniodo. A.D \& Ayalogu. D.J. (2012). ICT And The Teaching And Learning Of Physical And Health Education In Secondary Schools In Nigeria. Bassey Andah Journal. Vol. 5. 120-129

Botagariyev. T. A., dkk. (2016). Studying the Effectiveness of Physical Education In the Secondary School. International Journal of Environmental \& Science Education. Vol. 11, No. 10, 3575-3594.

Bungkaes, H. R., Posumah, J. H., \& Kiyai, B. (2013). Hubungan Efektivitas Pengelolaan Program Raskin dengan Peningkatan Kesejahteraan Masyarakat di Desa Mamahan Kecapatan Gemeh Kabupaten Kepulauan Talaud. Journal "Acta Diurna".

Casey, A. \& Jones, B. (2011). Using digital technology to enhance student engagement in physical education. Asia-Pacific Journal of Health, Sport and Physical Education. 2 (2), 51-66

Cawley, J., Frisvoldc, D., \& Meyerhoeferd, C. (2013). The impact of PE on obesity among elementary school children. Journal of Health Economics, 32, 743 755.

Collins. O., (2011). The Use Of Ict In Teaching and Learning Of Physical Education. Continental J. Education Research 4 (2): $29-32$.

Harvianto, Y. (2020). Dampak Program Sport Area Terhadap Penguatan Ekonomi Masyarakat di Kota Palangka Raya. Jurnal Ilmiah Mandala Education. Vol. 6. No. 1. Hal 1-5.

Mauro. H., Peter. H., (2017). Sport Education In A Higher Education Physical Activity Course. European Journal of Physical Education and Sport Science. Volume 3, issue 6. (22-35). 
Rodríguez, M. (2015). Information and Communication Technologies (ICT) in physical education. A theoretical review. Sportis Scientific Technical Journal, 1 (1), 75-86.

Rosdiani, Dini. (2013). Model Pembelajaran Langsung Dalam Pendidikan Jasmani dan Kesehatan. Bandung: Alfabeta.

Solihin, D. M., Faisal, A., \& Dadang, S. (2013). Kaitan antara Status Gizi, Perkembangan Kognitif, dan Perkembangan Motorik pada Anak Usia Prasekolah. Penelitian Gizi dan Makanan. 36(1), 62-72.

Sugiyono. (2017). Metode Penelitian Kuantitatif, Kualitatif, dan R\&D. Bandung : CV. Alfabeta 